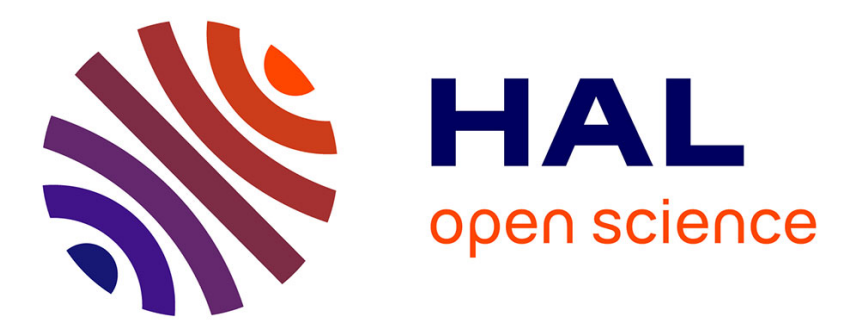

\title{
Characterization of Erwinia pyrifoliae, a novel pathogen of Asian pears
}

K. Geider, W.-S. Kim, S. Jock, Louis Gardan, Jean-Pierre Paulin, S.L. Rhim

\section{To cite this version:}

K. Geider, W.-S. Kim, S. Jock, Louis Gardan, Jean-Pierre Paulin, et al.. Characterization of Erwinia pyrifoliae, a novel pathogen of Asian pears. Plant Pathogenic Bacteria, Jul 2000, Charlottetown, Prince Edward Island, Canada. 445 p., 10.1007/978-94-010-0003-1 . hal-01600801

\section{HAL Id: hal-01600801 https://hal.science/hal-01600801}

Submitted on 4 Jun 2020

HAL is a multi-disciplinary open access archive for the deposit and dissemination of scientific research documents, whether they are published or not. The documents may come from teaching and research institutions in France or abroad, or from public or private research centers.
L'archive ouverte pluridisciplinaire HAL, est destinée au dépôt et à la diffusion de documents scientifiques de niveau recherche, publiés ou non, émanant des établissements d'enseignement et de recherche français ou étrangers, des laboratoires publics ou privés.

\section{다(1)(2)}

Distributed under a Creative Commons Attribution - ShareAlikel 4.0 International 


\section{Characterization of Erwinia pyrifoliae, a Novel Pathogen of Asian Pears}

Geider, K., Kim, W.-S., Jock, S., ${ }^{1}$ Gardan, L., ${ }^{1}$ Paulin, J.-P., ${ }^{2}$ Rhim, S.-L. $\quad$ MPI f. Zellbiologie, Rosenhof, Ladenburg, Germany; ${ }^{1}$ INRA, Angers, France; ${ }^{2}$ Hallym University, Chuncheon, South Korea. Email: kgeider@zellbio.mpg.de

\section{Introduction}

Necrotic symptoms of aerial parts of European and Asian pear trees (Pyrus communis L. and Pyrus pyrifolia Nakai) are often related to a well known bacterial disease of Maloideae: fire blight caused by $E$. amylovora (8). Nevertheless, Pseudomonas syringae pv. syringae causes pear blast on blossoms. Enterobacter pyrinus has been isolated in Korea (4) from necrotic leaf spots and shoots.

A recently observed necrotic disease of Asian pear fruit trees (Pyrus pyrifolia cv. 'Shingo' and 'Mansamgil') near Chuncheon in Korea has resulted in isolation and partial characterization of a bacterial pathogen (7). Most of result from colony morphology shows similarity with E. amylovora, but microbiological assays and absence of the PCR signals specific to E. amylovora distinguished the bacteria. The new pathogen was also different from Ent. pyrinus (4) in cultural, physiological and biochemical characteristics (7). Our findings resulted in the description of a new species: Erwinia pyrifoliae. A bacterial pathogen from Nashi pear fruit trees in Japan (\#) was obtained from Dr. S. Beer, Ithaka, and seems to be related to this species.

\section{Results and Discussion}

Origin of the Asian pear pathogen. Bacterial populations isolated from necrotic leaves and bark sampled from pear tree formed colonies on $\mathrm{MM} 2 \mathrm{Cu}$ agar (3) with a slightly yellow color and a mucoid appearance. When inoculated on slices of immature pears (Pyrus communis), the strains formed ooze. Inoculation of $E$. pyrifoliae on seedlings from Asian pears (P. pyrifolia) and European pears $(P$. communis) induced progressive necrosis along the midrib of leaves and blackening of petioles. On apple seedlings such symptoms were only occasionally induced by the Asian pear pathogen. No significant virulence symptoms were observed on cotoneaster, hawthorn, raspberry and plum. The bacteria, consistently obtained from diseased Asian pear trees in Korea, have apparently a more narrow host range than $E$. amylovora.

Classification of the pathogen. According to the description of phytopathogens within the Enterobacteriaceae (5), these strains belong to the genus Erwinia. The type strain Ep16/96 (CFBP 4172) and three other strains were related at $89 \%$ to $100 \%$ to each other based on DNA hybridization kinetics. $E$. amylovora strains were $40 \%$ to $52 \%$ related to the type strain of $E$. pyrifoliae with a $\Delta T m$ above $5^{\circ} \mathrm{C}\left(5.2\right.$ to $\left.6.8^{\circ} \mathrm{C}\right)$. A numerical taxonomy study and Biotype 100 strips confirmed that the Korean strains constituted a discrete phenon of a new species. 
Table 1. Different features for E. pyrifoliae and the Japanese Erwinias compared to E. amylovora.

- Similar EPS but not identical genes for synthesis

- No levan production on LB agar containing sucrose

- Utilization of some carbon sources used for typing

- Dendrogram from Biotype 100 assays*

- Different plasmids

- No PCR signal with primers from plasmid pEa29 and the ams region of $E$. amylovora

- Different pattern in PFGE analysis

- Low homology of the DNA sequence in the 16S-23S rRNA intergenic transcribed spacer region(ITS) and tRNA ${ }^{\text {Glu }}$

- DNA/DNA hybridization kinetics and thermal stability of genomic DNA*

*, not determined for the Erwinia strains from Japan.

Plasmids from E. pyrifoliae and PFGE analysis. The $29 \mathrm{~kb}$ plasmid of $E$. amylovora was not detected in E. pyrifoliae strains. A larger plasmid than $29 \mathrm{~kb}$ was visible and three additional plasmids of 2 to $4 \mathrm{~kb}$. The number, sizes and restriction patterns of the plasmids from both strains distinguished the two species from each other. No PCR signal was obtained from E. pyrifoliae with plasmid (2) or chromosomal primers (1) from E. amylovora.

Genomic DNA of $E$. pyrifoliae strains was digested with restriction enzymes $\mathrm{XbaI}$ and SpeI and subsequently analyzed by PFGE. For both enzymes the fragment patterns were different from E. amylovora. In the SpeI digest at least three different, but related patterns were observed showing some heterogeneity for the isolated E. pyrifoliae strains.

A pear pathogen from Japan. From Nashi pear fruit trees in Japan, bacteria were isolated, which ressembeled $E$. pyrifoliae in many aspects. They contained several plasmids, and did not react with the plasmid and ams of $E$. amylovora. On the other hand, they produced a PCR signal with the $E$. pyrifoliae cps primers and three out of five strains with the ITS primers of $E$. pyrifoliae. Digestion with restriction enzyme HaeIII resulted in the same fragments as for E. pyrifoliae. The PFGE pattern was unrelated to E. amylovora, but did also not fit into the three observed PFGE types of $E$. pyrifoliae. It can be assumed that the Erwinia strains from Japan and E. pyrifoliae are related but diverged in evolution.

Detection of E. pyrifoliae. EPS capsules of E. pyrifoliae can be stained by lectin from Abrus precatorius, which binds to amylovoran. The chromosomal region with the gene corresponding to amsB of $E$. amylovora was cloned and sequenced. PCR primers were deduced, which were specific for $E$. pyrifoliae and did also not cross-react with E. amylovora.

Unlike the 16S rRNA, the intergenic transcribed spacer region (ITS) regions of E. pyrifoliae was divergent from E. amylovora, Ent. pyrinus and $P$. stewartii subsp. stewartii including the the $\mathrm{RRNA}^{\mathrm{Glu}}$ gene. A dendrogram for ITSsequences of related bacteria showed an evolutionary distance of $E$. pyrifoliae 
to E. amylovora and other bacteria. Another primer pair was thus designed from the ITS region of E. pyrifoliae, and the $0.7 \mathrm{~KB}$ PCR fragment obtained was specific for the pathogen.

\section{Conclusions}

A novel pathogen was isolated from necrotic Nashi pear fruit trees in Korea and produced similar symptoms as E. amylovora on pear seedlings. It differed from E. amylovora in many microbiological and molecular criteria (Table 1) and has been described as the new species Erwinia pyrifoliae within the genus Erwinia. Erwinia strains from Nashi pear fruit trees in Japan ressembled $E$. pyrifoliae. When orchards in South Korea were screened for disease symtpoms, E. pyrifoliae was rarely recovered in 1999 and 2000.

\section{References}

1. Bereswill, S., Bugert, P., Bruchmüller, I., and Geider, K. 1995. Identification of Erwinia amylovora by PCR with chromosomal DNA. Appl. Environ. Microbiol. 61: 2636-2642

2. Bereswill, S., Pahl, A., Bellemann, P., Zeller, W., and Geider, K. 1992. Sensitive and species-specific detection of Erwinia amylovora by PCRanalysis. Appl. Environ. Microbiol. 58: 3522-3526

3. Bereswill, S., Jock, S., Bellemann, P., and Geider, K. 1998. Identification of Erwinia amylovora by growth morphology on agar containing cupper sulfate and by capsule staining with lectin. Plant Disease 82: 158-164

4. Chung, Y.R., Brenner, D.J., Steigerwalt, A.G., Kim, H.T., and Cho K.Y. 1993. Enterobacter pyrinus sp. nov. an organism associated with brown leaf spott disease of pear tree. Internat. J. Syst. Bacteriol. 43: 157-161

5. Hauben, L., Moore, E.R., Vauterin, L., Steenackers, M., Mergaert, J., Verdonck, L., and Swings, J. 1998. Phylogenetic position of phytopathogens within the Enterobacteriaceae. Systematic \& Applied Microbiology. 21: 384-97.

6. Kim, W.-S., Gardan, L., Rhim, S.-L., and Geider, K. 1999. Erwinia pyrifoliae sp. nov., a novel pathogen affecting Asian pear trees (Pyrus pyrifolia Nakai). Int. J. System. Bacteriol. 49: 899-906.

7. Rhim, S.-L., Völksch, B., Gardan, L., Paulin, J.-P., Langlotz, C., Kim, W.-S., and Geider, K. 1999. Erwinia pyrifoliae, an Erwinia species different from Erwinia amylovora, causes a necrotic disease of Asian pear trees. Plant Pathology 48: 514-520.

8. Van der Zwet, T., and Beer S.V. 1995. Fire blight-Its nature, prevention, and control: A practical guide to integrated disease management. U.S. Department of Agriculture, Agricultural Information Bulletin. 631: 91 pp. 